\title{
Actions of thermal stress in two-cell bovine embryos: oxygen metabolism, glutathione and ATP content, and the time-course of development
}

\author{
Rocío Melissa Rivera ${ }^{1}$, Gabriella M Dahlgren ${ }^{2}$, Luiz Augusto de Castro e Paula ${ }^{1}$, \\ Robert T Kennedy ${ }^{2}$ and Peter J Hansen ${ }^{1}$ \\ ${ }^{1}$ Department of Animal Sciences, University of Florida, Gainesville, Florida 32611-0910, USA and ${ }^{2}$ Department \\ of Chemistry, University of Michigan, Ann Arbor, Michigan 48109, USA
}

Correspondence should be addressed to P J Hansen; Email: Hansen@animal.ufl.edu

(R M Rivera is now at Department of Biology, University of Pennsylvania, Philadelphia, Pennsylvania 19104-6018, USA)

\begin{abstract}
The mechanism by which heat shock disrupts development of the two-cell bovine embryo was examined. The reduction in the proportion of embryos that became blastocysts caused by heat shock was not exacerbated when embryos were cultured in air $\left(20.95 \% \mathrm{O}_{2}\right)$ as compared with $5 \% \mathrm{O}_{2}$. In addition, heat shock did not reduce embryonic content of glutathione, cause a significant alteration in oxygen consumption, or change embryonic ATP content. When embryos were heat-shocked at the two-cell stage and allowed to continue development until $72 \mathrm{~h}$ post insemination, heat-shocked embryos had fewer total nuclei and a higher percentage of them were condensed. Moreover, embryos became blocked in development at the eight-cell stage. The lack of effect of the oxygen environment on the survival of embryos exposed to heat shock, as well as the unchanged content of glutathione, suggest that free radical production is not a major cause for the inhibition in development caused by heat shock at the two-cell stage. In addition, heat shock appears to have no immediate effect on oxidative phosphorylation since no differences in ATP content were observed. Finally, the finding that heat shock causes a block to development at the eight-cell stage implies that previously reported mitochondrial damage caused by heat shock or other heat shock-induced alterations in cellular physiology render the embryo unable to proceed past the eight-cell stage.

Reproduction (2004) 128 33-42
\end{abstract}

\section{Introduction}

Exposure of preimplantation embryos to elevated temperature causes disruption of continued development (Alliston et al. 1965, Elliot et al. 1968, Gwazdauskas et al. 1992, Rivera \& Hansen 2001). Temperatures causing this effect represent a relatively mild elevation over hyperthermic temperatures. In cattle embryos, for example, $41.0^{\circ} \mathrm{C}$ can block development as compared with culture at $38.5^{\circ} \mathrm{C}$ (Rivera \& Hansen 2001, Rivera et al. 2003). An elevation in culture temperature of only $2.0^{\circ} \mathrm{C}$ (from 37.0 to $39.0^{\circ} \mathrm{C}$ ) reduced development of mouse embryos (Gwazdauskas et al. 1992). Since temperatures reducing development are within the range of temperatures experienced by heat-stressed females, it is likely that the disruption of embryonic development caused by thermal stress is of physiological relevance to the reduction in fertility experienced by heat-stressed females (Elliot \& Ulberg 1971, Wettemnn \& Bazer 1985, Putney et al. 1988, Ealy et al. 1993).
Little is known about the mechanisms by which mild elevations in temperature cause such catastrophic effects on the preimplantation embryo. Most of the literature dealing with effects of heat shock on cells involves much higher temperatures - commonly $43.0^{\circ} \mathrm{C}-45.0^{\circ} \mathrm{C}$ - and the molecular and cellular changes affected by these temperatures may not occur in embryos exposed to $41.0^{\circ} \mathrm{C}$.

One possible action of heat shock is to increase free radical production by the embryo. Heat shock of cells has been shown to increase the flux of cellular free radicals (Flanagan et al. 1998) by uncoupling mitochondria, one of the main reactive oxygen species generators, as well as by activating enzymes which are involved in the generation of free radicals (Skibba et al. 1989). The major evidence that heat shock increases free radicals in embryos comes from the mouse, where thermal stress has been shown to increase intracellular hydrogen peroxide production (Ozawa et al. 2002) and decrease intracellular content of 
the antioxidant glutathione (Aréchiga et al. 1995). In addition, mouse embryos (Aréchiga et al. 1995, Aréchiga \& Hansen 1998) can be made more resistant to heat shock by addition of antioxidants in the culture medium. Induced thermotolerance in mouse embryos can be blocked by inhibition of glutathione synthesis (Aréchiga et al. 1995).

Exposure of bovine two-cell embryos to $41.0^{\circ} \mathrm{C}$ for $6 \mathrm{~h}$ resulted in a $15 \%$ increase in the number of mitochondria undergoing swelling (Rivera et al. 2003). Heat shock has also been demonstrated to cause mitochondrial swelling in other cell types (Welch \& Suhan 1985, Cole \& Armour 1988, Funk et al. 1999). Mitochondrial swelling is a phenomenon which results from loss of membrane potential as a result of the opening of the high conductance permeability transition pores on the inner mitochondrial membrane (Halestrap et al. 2002). Increased calcium and generation of reactive oxygen species promote permeability transition pore opening which, in turn, causes uncoupling of oxidative phosphorylation and prevents mitochondria from synthesizing ATP (Lemasters 1999, Halestrap et al. 2002). In non-embryonic cells, temperatures in the range of $41.0^{\circ} \mathrm{C}$ can impair electron transport along the respiratory chain (Floridi et al. 1987) and thereby decrease the amount of ATP and phosphorylation efficiency (Findly et al. 1983, Calderwood 1987, Macouillard-Poulletier de Gannes et al. 1998). Oxygen consumption would be expected to decline in heat-shocked cells undergoing mitochondrial damage. In fact, the respiratory properties of microglial cells were compromised during and immediately after heat shock with an immediate drop in oxygen consumption (Macouillard-Poulletier de Gannes et al. 2000).

There were three objectives for the present study. The first was to evaluate the possible role of free radicals in disruption of embryonic development caused by a heat shock. This question was evaluated by determining whether the magnitude of the reduction in development caused by heat shock was reduced by lowering oxygen tension and by determining whether heat shock reduced embryonic content of glutathione, the major cytoplasmic antioxidant in the cell. The second objective was to determine whether heat shock altered oxygen consumption and ATP content of the embryo in a manner consistent with a change in blastomere function caused by increased mitochondrial damage. The third objective of this study was to determine the time point in development at which heat shock at the two-cell stage blocks development, i.e. whether heat shock causes an immediate inhibition of development or rather compromises the ability of the embryo to proceed through the eight-cell stage, around the time when embryos begin major transcriptional activity (Memili \& First 2000).

\section{Materials and Methods \\ In vitro production of embryos}

Procedures, reagents, and media formulation for oocyte maturation, fertilization, and embryo culture were as described elsewhere (Rivera \& Hansen 2001, Rivera et al. 2003, Soto et al. 2003). Except for one experiment described later, all incubations were performed in an atmosphere of $\mathrm{CO}_{2}$ in humidified air. Briefly, ovaries were collected at a local abattoir located at a travel distance of approximately $1.5 \mathrm{~h}$ from the laboratory. Oocytes obtained by slashing the ovary were matured for approximately $21 \mathrm{~h}$ and then inseminated with a cocktail of Percoll-purified spermatozoa from three different Angus bulls; a different group of bulls was used for each replicate. At 12-18 hours post-insemination (hpi), putative zygotes were denuded of cumulus cells by suspension in Hepes-TALP medium containing 1000 units/ml hyaluronidase type IV (Sigma, St Louis, MO, USA) and vortexing in a microcentrifuge tube. Presumptive zygotes were then placed in groups of $\sim 30$ in $50 \mu \mathrm{l}$ microdrops KSOM. For most experiments, the specific formulation KSOM-BE1 was used (Soto et al. 2003). In one experiment, however, after the supplier changed the formulation for KSOM, a different formulation called KSOM-BE2 (Soto et al. 2003) was used. Rates of development and effects of heat shock were similar in both formulations (RM Rivera \& PJ Hanson, unpublished observations).

\section{Heat shock treatment}

Two-cell embryos were collected at 28-30 hpi and cultured in fresh microdrops of KSOM-BE1 or KSOM-BE2 at one of two temperatures: $38.5^{\circ} \mathrm{C}$ (i.e. homeothermic body temperature of the cow) or $41.0^{\circ} \mathrm{C}$ (characteristic temperature for heat-stressed cows; Rivera \& Hansen 2001). After $6 \mathrm{~h}$, embryos were either collected and analyzed for oxygen consumption, glutathione content or ATP content, or returned to the control temperature $\left(38.5^{\circ} \mathrm{C}\right)$ until day 3 or 8 post insemination when subsequent development was assessed. All cultures at $38.5^{\circ} \mathrm{C}$ were performed in an environment of $5 \% \mathrm{CO}_{2}$ in humidified air except where otherwise specified. The percentage $\mathrm{CO}_{2}$ was adjusted to $7 \%$ in the incubator used for heat shock to maintain the $\mathrm{pH}$ of the medium at a similar value as that of the control incubator ( 7.4; Rivera \& Hansen 2001). The temperatures of all incubators were calibrated routinely to assure accuracy of treatments.

\section{Effects of oxygen tension on inhibition of development caused by heat shock}

This experiment was performed to determine if culture in a low oxygen environment $(5 \%)$ would reduce the effects of heat shock on development as compared with culture in air (20.95\% oxygen). The design was a $2 \times 2$ factorial in which two temperatures $\left(38.5\right.$ and $\left.41.0^{\circ} \mathrm{C}\right)$ and two 
oxygen tensions (5 and 20.95\%) were tested. Embryos were cultured in either a high or low oxygen environment for the duration of the experiment beginning after removal from fertilization drops. For cultures under a low oxygen environment, the gaseous phase was $5 \% \mathrm{CO}_{2}, 5 \% \mathrm{O}_{2}$, and $90 \% \mathrm{~N}_{2}$ for the control incubator and $7 \% \mathrm{CO}_{2}, 5 \%$ $\mathrm{O}_{2}$, and $88 \% \mathrm{~N}_{2}$ for the heat shock incubator. Approximately $30 \mathrm{hpi}$, two-cell embryos were placed in fresh microdrops of KSOM-BE2 and cultured for $9 \mathrm{~h}$ at one of two temperatures in high or low oxygen tension. Embryos cultured at $41.0^{\circ} \mathrm{C}$ were returned to the control temperature (i.e. $38.5^{\circ} \mathrm{C}$ ) after $9 \mathrm{~h}$. Development to the blastocyst stage was evaluated on day 8 post insemination. The experiment was replicated four times with a total of 5377 two-cell embryos/treatment.

\section{Effects of heat shock on glutathione content}

\section{Glutathione recycling assay}

Embryos were collected at the two-cell stage at approximately $28 \mathrm{hpi}$, placed in fresh drops of KSOM-BE1, and cultured at 38.5 or $41.0^{\circ} \mathrm{C}$ for $6 \mathrm{~h}$. Immediately after the 6-h culture, groups of 16-20 two-cell heat-shocked or control embryos were suspended in $5 \mu \mathrm{l} \mathrm{KSOM-BE1}$ and stored at $-20.0^{\circ} \mathrm{C}$ until analyzed for glutathione content. Glutathione content of embryos was determined as previously described (Aréchiga et al. 1995) by the use of the glutathione recycling assay (Baker et al. 1990). This method is based on the reduction of 5,5-dithiobis (2-nitrobenzoic acid; DNTB) to 2-nitro-5-thiobenzoic acid (a yellow colored product) by glutathione and the recycling of glutathione disulfide to glutathione by glutathione reductase. On the day of the assay, groups of embryos were suspended in $45 \mu \mathrm{l}$ deionized water and pipetted into separate wells of a 96-well microtiter plate. In addition to the embryo samples, $50 \mu$ l of standard $(0-100$ pmol glutathione per well) were pipetted into duplicate wells. This was immediately followed by the addition of $100 \mu$ l reaction mixture (prepared by mixing $5.75 \mathrm{ml} 100 \mathrm{mM} \mathrm{NaPO}_{4}$ buffer with $1 \mathrm{mM}$ EDTA, pH 7.5, $5 \mathrm{ml} 1 \mathrm{mM}$ DNTB, $5 \mathrm{ml}$ $1 \mathrm{mM} \mathrm{NADPH}$, and $0.1 \mathrm{ml} 200 \mathrm{U} / \mathrm{ml}$ glutathione reductase dissolved in $\mathrm{NaPO}_{4}-$ EDTA buffer) to the embryo samples or standards (all chemicals for the assay were from SigmaAldrich). Absorbance was read at $405 \mathrm{~nm}$ after $\sim 6-8 \mathrm{~min}$ incubation using a microtiter plate reader (model EL 309; BIO-TEK Instruments Inc.). The experiment was replicated on 7 different days so that seven pools of embryos (16-20 embryos/pool) were assayed for each treatment.

\section{Effects of heat shock on oxygen consumption}

\section{Electrode preparation}

All chemicals were obtained from Sigma-Aldrich at the highest available purity level unless otherwise stated. Solutions were made with deionized water from a Milli-Q Plus system water purifier (Millipore Co., Bedford, MA, USA). The epoxy Epon 828 with m-phenylenediamine as the curing agent was purchased from Miller-Stephenson (Dandury, CT, USA). Oxygen sensing electrodes were manufactured following a previously described protocol (Jung et al. 1999a). Briefly, a $1.5 \mathrm{~cm}$ by $25 \mu \mathrm{m}$ diameter platinum wire was attached to a 27-gauge syringe needle using silver epoxy (Epoxy Technology, Billerica, MA, USA). The needles were baked for $1 \mathrm{~h}$ at $100^{\circ} \mathrm{C}$. After baking, the platinum wire was immersed in a solution of $3 \mathrm{M}$ $\mathrm{KCN}$ and $1 \mathrm{M} \mathrm{KOH}$ while a $3.4 \mathrm{~V}$ square wave at a frequency of $250 \mathrm{~Hz}$ was applied for 6-8 min to etch the platinum wire to $1-3 \mu \mathrm{m}$ diameter. The etched platinum wire and needle were then placed inside a pulled glass capillary that had been cut at the end such that the wire protruded from the tip. Next, the electrodes were dipped into epoxy (Epon 828 with $m$-phenylenediamine as the curing agent) and were allowed to dry overnight followed by curing at $100^{\circ} \mathrm{C}$ for $2 \mathrm{~h}$ and then at $150{ }^{\circ} \mathrm{C}$ for an additional $2 \mathrm{~h}$. After curing, a second etching procedure was undertaken under the same conditions as described above, with the exception that $\mathrm{KOH}$ was not present, to recess the electrode. The second etching step proceeded until the platinum wire was recessed $2-3 \mu \mathrm{m}$ into the end of the glass pipette. The electrodes were then dipped into $7 \%(\mathrm{w} / \mathrm{w})$ cellulose acetate in tetrahydrofuran for $60 \mathrm{~s}$. The final diameter of the electrodes was $2-5 \mu \mathrm{m}$.

All electrodes were tested and calibrated by addition of $\mathrm{N}_{2}$, air, and $\mathrm{O}_{2}$ to a solution at the electrodes. These solutions corresponded to partial pressures of oxygen of 0 , 150 and $720 \mathrm{~mm} \mathrm{Hg}$ respectively. Testing was performed with the electrodes immersed in Krebs' Ringer buffer (KRB) which consisted of $118 \mathrm{mM} \mathrm{NaCl}, 5.4 \mathrm{mM} \mathrm{KCl}$, $2.4 \mathrm{mM} \mathrm{CaCl}_{2}, 1.2 \mathrm{mM} \mathrm{MgSO}{ }_{4}, 1.2 \mathrm{mM} \mathrm{KH}_{2} \mathrm{PO}_{4}$, and $20 \mathrm{mM}$ Hepes at pH 7.4.

\section{Oxygen consumption measurements}

Embryos were collected at the two-cell stage at approximately $28 \mathrm{hpi}$, placed in fresh drops of KSOM-BE1, and cultured at 38.5 or $41.0^{\circ} \mathrm{C}$ for $6 \mathrm{~h}$. Immediately after the 6-h culture, two-cell embryos were transferred to fresh KSOM-BE1 medium and transported in a portable incubator (Minitube, Verona, WI, USA) set at $39.0^{\circ} \mathrm{C}$. Embryos were then incubated at $38.5^{\circ} \mathrm{C}$ in $5 \% \mathrm{CO}_{2}$ on a poly-Llysine coated Petri dish for 20-30 min in KSOM-BE1. The Petri dish was transferred to a micro-incubator on the stage of a Zeiss Axiovert 35 microscope where the KRB was maintained at $37.0^{\circ} \mathrm{C}$. Stabilization of the electrodes was performed by positioning the electrodes 100-200 $\mu \mathrm{m}$ away from the embryo. Once a stable baseline was observed for 2-5 min, the electrode was positioned $10-20 \mu \mathrm{m}$ away from the embryo and measurements taken. The electrode was then inserted into the perivitelline space of the embryo and measurements recorded for $2 \mathrm{~min}$. The electrode was repositioned outside the embryo $(10-20 \mu \mathrm{m})$ and the measurement process repeated at least three times on each embryo (i.e. the electrode was inserted at least three times through the zona). 
Oxygen measurements were performed by applying a potential with a battery to a saturated sodium calomel electrode and using a Keithley 428 current amplifier to measure the current from the working electrode. The potential at the working electrode was $-0.6 \mathrm{~V}$ vs sodium saturated calomel electrode. The data were collected via a data acquisition board (Axon Digidata 1200) from Axon Instruments, Inc. (Foster City, CA, USA) and a personal computer using Axoscope 8.1 software. Data were collected at $100 \mathrm{~Hz}$ and low-pass filtered at $20 \mathrm{~Hz}$. The oxygen concentration was determined by using the calibration curve. Oxygen consumption was calculated for each embryo as the difference in partial pressure of oxygen between measurements taken inside and outside the zona pellucida. These values were converted to $\mathrm{mol} / \mathrm{s}$ using an equation described by Mueller-Klieser (1984) and assuming the diameter of the embryo was $120 \mu \mathrm{m}$. The experiment was replicated three times with a total of 7-8 two-cell embryos/treatment.

\section{Effects of heat shock on ATP content}

\section{ATP assay}

Embryos were collected at the two-cell stage at approximately $28 \mathrm{hpi}$, placed in fresh drops of KSOM-BE1, and cultured at 38.5 or $41.0^{\circ} \mathrm{C}$ for $6 \mathrm{~h}$. The ATP assay was performed on pooled groups of 3-5 two-cell embryos per treatment immediately after the 6 - $\mathrm{h}$ culture period. The ATP determination kit, from Molecular Probes (Eugene, OR, USA), is a bioluminescence assay based on the requirement of firefly luciferase for ATP to produce light. The standard reaction solution was prepared following the manufacturer's specifications. A series of freshly prepared ATP standards $(0.08$ to $5 \mathrm{pmol} /$ tube dissolved in distilled water) were used to generate a standard curve. The assay consisted of the addition of $10 \mu \mathrm{l}$ embryos $(8 \mu \mathrm{l}$ distilled water plus $\sim 2 \mu \mathrm{l}$ embryos and culture medium) or $10 \mu \mathrm{l}$ standards to $100 \mu$ l reaction mixture. Luminescence was detected with the use of a luminometer (AutoLumat LB953, Wallac Inc., Gaithersburg, MD, USA). Reaction mixture was added automatically by the luminometer immediately prior to measurement and each sample was measured for $5 \mathrm{~min}$. The experiment was replicated on eight different days with a total of 21 pools $\left(38.5^{\circ} \mathrm{C}\right)$ or 24 pools $\left(41.0^{\circ} \mathrm{C}\right)$ of $3-5$ two-cell embryos.

\section{Effects of heat shock at the two-cell stage on subsequent development to day 3 post-insemination}

Embryos were collected at the two-cell stage at approximately $28 \mathrm{hpi}$, placed in fresh drops of KSOM-BE1, and cultured at 38.5 or $41.0^{\circ} \mathrm{C}$ for $6 \mathrm{~h}$. Culture dishes containing heat-shocked embryos were returned to the control temperature until $72 \mathrm{hpi}$. Embryos were fixed in 4\% paraformaldehyde (purchased as an 8\% solution from Electron Microscopy Sciences, Fort Washington, PA, USA) in $0.2 \mathrm{M}$ $\mathrm{NaPO}_{4}$, pH 7.4 containing $0.15 \mathrm{M} \mathrm{NaCl}$ (phosphate-buffered saline; PBS) for $1 \mathrm{~h}$. Nuclei of embryos were then stained with a $1 \mu \mathrm{g} / \mathrm{ml}$ solution of Hoechst 33342 dye in PBS supplemented with $1 \mathrm{mg} / \mathrm{ml}$ polyvinyl pyrrolidone (PBS + PVP) for $45 \mathrm{~min}$. Embryos were washed three times in PBS + PVP prior to placing on glass slides containing $5 \mu \mathrm{l}$ ProLong antifade solution (Molecular Probes). Total and condensed nuclei were counted by viewing with a Zeiss Axioplan2 epifluorescent microscope (Carl Zeiss Inc., Gottingen, Germany). Images were acquired using AxioVision software and a high-resolution black and white AxioCam MRm digital camera (Carl Zeiss Inc., Thorwood, NY, USA). The experiment was replicated on four different days with 46 embryos/treatment.

\section{Statistical analysis}

Data were analyzed by least-squares analysis of variance using the General Linear Models procedure of SAS (SAS for Windows, Version 8e, Cary, NC, USA). In each case, replicate was considered as a random effect and other variables were considered as fixed effects. Tests of significance were made using error terms derived from the calculation of expected means squares. For the experiment to test the effect of oxygen tension on the response to heat shock, data subjected to analysis were the percentage of two-cell embryos that developed to the blastocyst stage calculated for each replicate. The mathematical model included main effects of temperature, oxygen tension, replicate, and their interactions. Percentage data were analyzed before and after transformation by arcsine transformation. Analysis of transformed data was used to obtain probability values while analysis of untransformed data was used to obtain least-squares means \pm S.E.M. For the ATP, glutathione and oxygen consumption experiments, the mathematical model included effects of temperature, replicate and temperature $\times$ replicate. For the experiment regarding effects of heat shock on development on day 3 after insemination, percentage data were calculated for each replicate and untransformed and arcsine-transformed data were analyzed using a mathematical model that included effects of temperature, replicate and temperature $\times$ replicate. All means presented in the paper are shown as least-squares means \pm S.E.M.

\section{Results}

\section{Effects of oxygen tension on inhibition of development caused by heat shock}

Incubation of two-cell embryos at $41.0^{\circ} \mathrm{C}$ for $9 \mathrm{~h}$ reduced $(P=0.06)$ the proportion of embryos that became blastocysts at day 8 after insemination (Fig. 1). The reduction in development occurred for embryos cultured under both low and high oxygen environments. There was a tendency $(P=0.08)$ for a greater proportion of embryos to form blastocysts under low oxygen tension than embryos cultured under the high oxygen environment. There was a temperature $\times$ oxygen tension interaction 


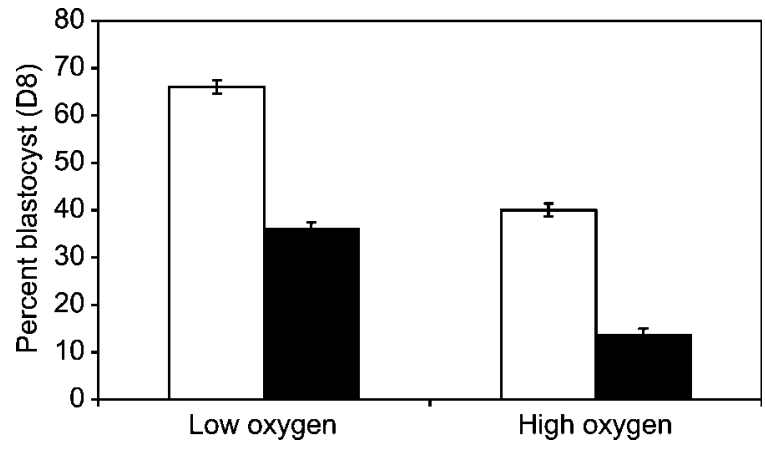

Figure 1 Effects of oxygen environment on response of two-cell embryos to heat shock. Data represent the proportion of two-cell embryos that became blastocysts at day 8 (D8) after insemination for embryos cultured in air (i.e. $20.95 \%$ oxygen; high oxygen) or under a low oxygen (5\%) environment. Open bars represent control embryos and solid bars represent heat-shocked embryos. Values are leastsquares means \pm S.E.M. of data from four replicates with 53-77 twocell embryos per treatment.

$(P<0.03)$ that reflects the numerically greater reduction in development caused by heat shock for embryos under low oxygen tension.

\section{Effect of heat shock on glutathione content}

There were no differences in glutathione content between control and heat-shocked embryos (3.42 \pm 0.42 vs $3.12 \pm$ $0.42 \mathrm{pmol} / \mathrm{embryo}$ for embryos cultured at $38.5^{\circ} \mathrm{C}$ and $41.0^{\circ} \mathrm{C}$ respectively).

\section{Effect of heat shock on ATP content}

Heat shock did not decrease embryonic content of ATP. Values were $0.26 \pm 0.06 \mathrm{pmol} / \mathrm{embryo}$ for embryos cultured at $38.5^{\circ} \mathrm{C}$ and $0.30 \pm 0.05$ pmol/embryo for embryos at $41.0^{\circ} \mathrm{C}$.

\section{Effect of heat shock on oxygen consumption}

Representative photomicrographs illustrating the placement of the electrode inside and outside the perivitelline space are shown in Fig. 2A while a representative pattern of changes in oxygen concentration as the electrode is moved from outside the zona pellucida to inside the perivitelline space is shown in Fig. 2B. There was no statistically significant effect of heat shock on concentrations of oxygen outside or inside the zona pellucida or on oxygen consumption (calculated as the difference between oxygen concentrations inside and outside the zona pellucida). Oxygen consumption was, however, numerically lower for heat-shocked embryos. Least-squares means \pm S.E.M. for oxygen consumption were $25.58 \pm 5.4 \mathrm{mmHg}$ $\left(\sim 2.8 \times 10^{-13} \mathrm{~mol} / \mathrm{s}\right)$ and $12.25 \pm 5.12 \mathrm{mmHg}(1.3 \times$ $\left.10^{-13} \mathrm{~mol} / \mathrm{s}\right)$ for 38.5 and $41.0^{\circ} \mathrm{C}$ respectively $(P=0.18)$.
A

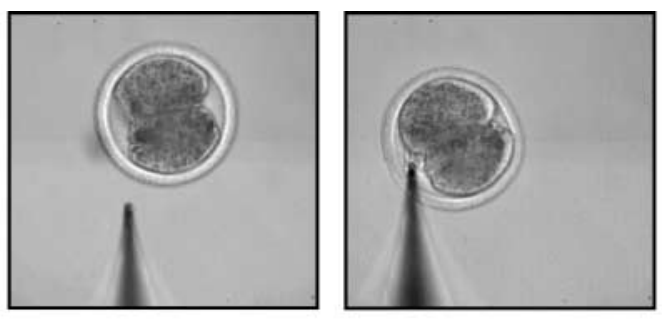

B

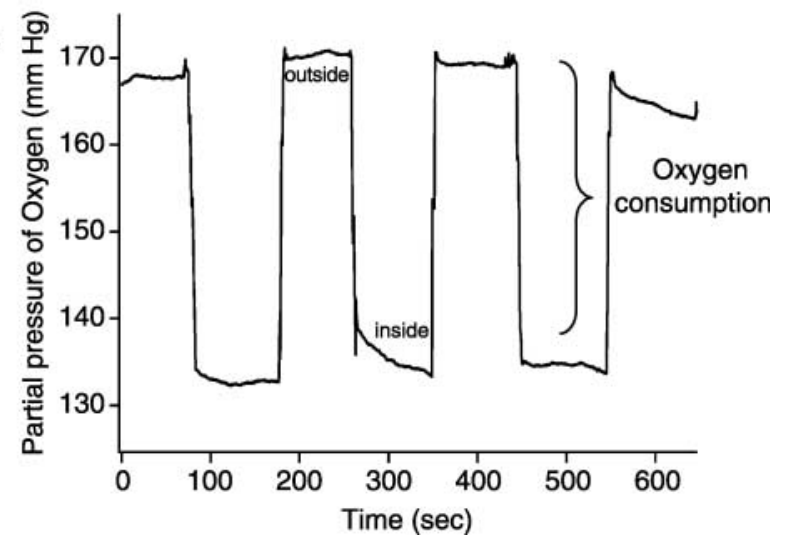

Figure 2 Method for measuring oxygen consumption of two-cell bovine embryos. (A) Photomicrographs illustrating the placement of oxygen electrodes outside and in close proximity to the zona pellucida (left) or inside the perivitelline space (right). (B) Typical pattern of changes in oxygen concentration as the electrode is moved from outside the zona pellucida to inside the perivitelline space.

\section{Effects of heat shock at the two-cell stage on subsequent development to day 3 post-insemination}

Representative images illustrating formation of condensed nuclei in embryos are shown in Fig. 3 while least-squares means \pm S.E.M. for number of nuclei and number and percent of condensed nuclei are shown in Fig. 4A. Heat shock at the two-cell stage reduced $(P<0.05)$ the number of total nuclei from $10.3 \pm 0.6$ to $7.6 \pm 0.6$. Heat shock tended to increase $(P=0.08)$ the number of condensed nuclei $\left(0.43 \pm 0.12\right.$ and $1.12 \pm 0.12$ for 38.5 and $41.0^{\circ} \mathrm{C}$ respectively) and increased $(P<0.01)$ the percentage of nuclei that were condensed $(4.5 \pm 4.6$ vs $21.8 \pm 4.5 \%$ condensed for 38.5 and $41.0^{\circ} \mathrm{C}$ respectively).

The stage of development at $72 \mathrm{~h}$ after insemination was evaluated to determine whether embryos subjected to heat shock at the two-cell stage became blocked in development at a specific stage. The distribution of cell number at $72 \mathrm{hpi}$ is shown in Fig. 4B. It is apparent that heatshocked embryos became blocked in development at the eight-cell stage. Only $25 \pm 7 \%$ of the heat-shocked embryos developed past the eight-cell stage versus $67 \pm 7 \%$ of control embryos $(P<0.05)$. That the block to development occurred at this stage and not earlier was evident by the fact that heat shock did not affect the proportion of embryos developing past the two-cell stage $(100 \pm 0$ vs $98 \pm 15 \%)$ or four-cell stage (98 \pm 15 vs $96 \pm 21 \%)$. 

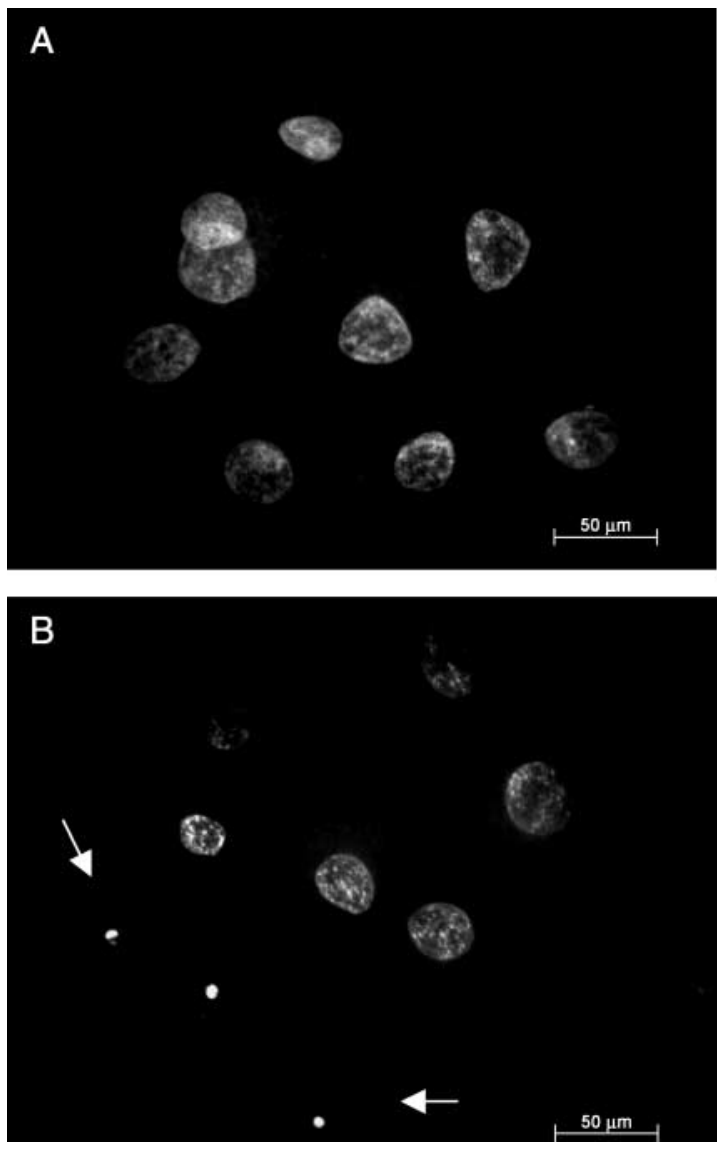

Figure 3 Effects of heat shock at the two-cell stage on condensed nuclei $72 \mathrm{~h}$ after insemination. The photomicrographs are representative images of control (A) or heat-shocked (B) embryos stained with Hoechst nuclear stain at $72 \mathrm{~h}$ post insemination. Arrows point to condensed nuclei. The sperm heads on the zona pellucida were digitally removed from the pictures.

\section{Discussion}

While it is well established that exposure to a mild heat shock decreases development of preimplantation embryos (Alliston et al. 1965, Elliot et al. 1968, Gwazdauskas et al. 1992, Aréchiga et al. 1995, Aréchiga \& Hansen 1998, Rivera \& Hansen 2001), the mechanisms by which development is inhibited are not known. Increased production of free radicals has been implicated in the preimplantation mouse embryo (Aréchiga et al. 1995, Aréchiga \& Hansen 1998, Ozawa et al. 2002) but present results do not support a critical role for free radicals in the two-cell bovine embryo. Other effects of heat shock in bovine two-cell embryos include an increase in the number of swollen mitochondria and cytoskeletal changes that lead to redistribution of organelles away from the periphery (Rivera et al. 2003, 2004). Here it was shown that these ultrastructural changes do not lead to an immediate alteration in ATP content or to inhibition of embryonic growth. Rather, a heat-shocked two-cell embryo can continue to undergo an additional two cleavage divisions until it
A
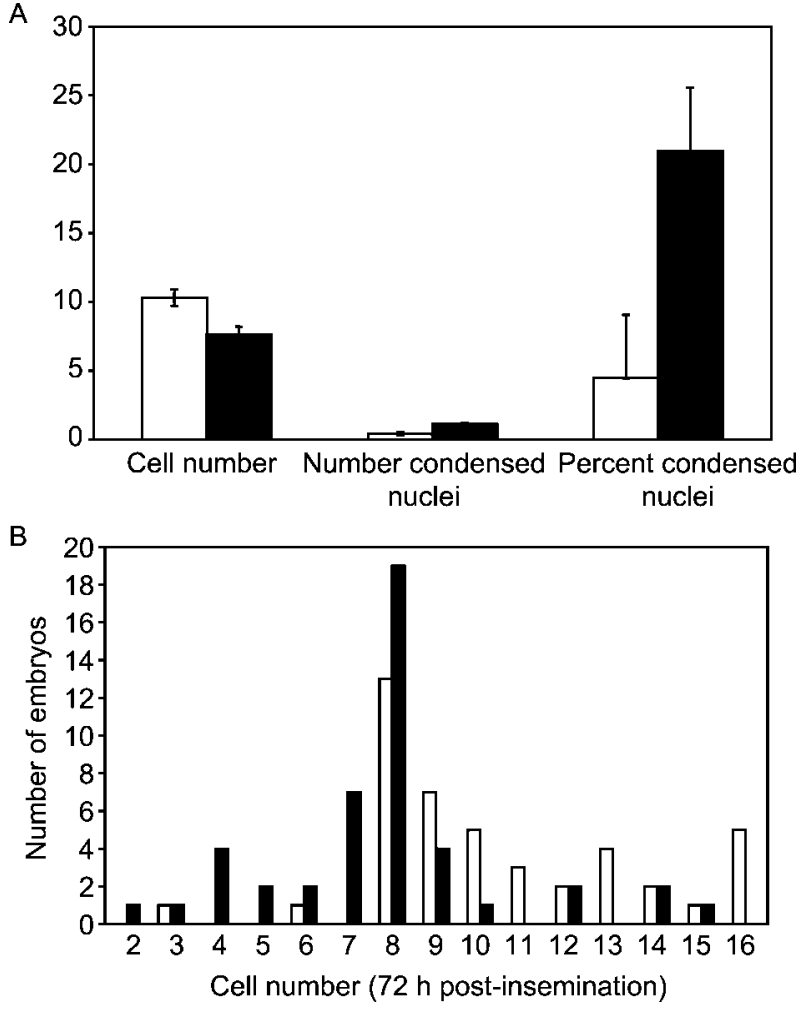

Figure 4 Effects of heat shock at the two-cell stage on the number of total and condensed nuclei $72 \mathrm{~h}$ after insemination. Data in panel $\mathrm{A}$ are least-squares means \pm S.E.M. for total number of nuclei and number and percent of condensed nuclei as affected by heat shock. (B) The distribution of cell number at $72 \mathrm{~h}$ post insemination. Open bars represent control embryos and solid bars represent heat-shocked embryos. The experiment was replicated four times with 45 embryos per treatment.

becomes blocked in development at the eight-cell stage. Thus, the partial loss of mitochondria and cytoskeletal alterations caused by heat shock (Rivera et al. 2003, 2004) do not appear to lead to critical alterations in embryonic physiology until the stage of development coincident with embryonic genome activation (Memili \& First 2000) and heat shock-induced apoptosis (Paula-Lopes \& Hansen 2002).

Recently, exposure of bovine embryos to heat shock at day 0 and 2 relative to fertilization has been reported to increase peroxide production (Sakatani et al. 2004). Nonetheless, results from the present experiments fail to support a critical role for free radicals in actions of heat shock on embryo development in cattle. This conclusion is based primarily on the finding that low oxygen content did not reduce the effects of heat shock. If an increase in free radicals was important for the inhibition of development, one would expect that effects of heat shock would be greater in the presence of high oxygen. Many oxidases that produce reactive oxygen species are known to be oxygen dependent (Fridovich 1964, Cohen \& Fridovich 1971) and the amount of oxygen radicals within mouse embryos is dependent upon the oxygen environment 
(Goto et al. 1993). Embryos cultured in low oxygen were not less sensitive to heat shock, however. In fact, the decrease caused by heat shock was slightly greater for embryos cultured in low oxygen than in air because overall rates of development at $38.5^{\circ} \mathrm{C}$ were greater. In an earlier study, also, exposure of embryos to a $5 \% \mathrm{O}_{2}$ environment during heat shock did not lessen the detrimental effects of heat shock when compared with control embryos (Rivera \& Hansen 2001). The lack of difference in the content of glutathione between heat-shocked and control embryos is additional evidence that free radicals are not a major source of damage to the two-cell embryo, at least in the cytosol where glutathione is the major antioxidant. It will be instructive to determine antioxidant status in the lipid compartment of the cell to determine whether the increased peroxide production caused by heat shock (Sakatani et al. 2004) depletes antioxidant stores in that compartment. Consistent with the idea that free radical production is not a crucial determinant of the effects of heat shock on bovine embryos are results from experiments in which addition of various antioxidants did not reduce the effects of heat shock on embryonic development (Ealy et al. 1995, Paula-Lopes et al. 2003).

In an earlier study, $15 \%$ of mitochondria of two-cell embryos exposed to $41.0^{\circ} \mathrm{C}$ for $6 \mathrm{~h}$ had become swollen (Rivera et al. 2003) Mitochondrial swelling is the result of a change in the conductance of the mitochondrial permeability transition pore to allow nonselective diffusion of large molecules into the matrix (Ichas \& Mazat 1998). A major consequence of the mitochondrial permeability transition is the uncoupling of oxidative phosphorylation as a result of a collapse of the membrane potential and $\mathrm{pH}$ gradient (Duchen 1999, Halestrap et al. 2002, Skulachev 2002) and a drop in the ATP/ADP ratio (Duchen 1999). Eventually, the swollen mitochondrion undergoes death in a process called mitoptosis (Skulachev 2002). Given these effects of heat shock on mitochondrial function, it was hypothesized that heat shock would result in a reduction in oxygen consumption. Since the contribution of ATP from glycolysis is low in the early preimplantation embryo and energy is largely generated by oxidative phosphorylation (Houghton et al. 1996, Thompson 2000), it was also expected that heat shock would cause the intracellular content of ATP to decline. Heat shock did not significantly reduce oxygen consumption, although it was numerically lower for embryos at $41.0^{\circ} \mathrm{C}$ and the high variation in measurements may have precluded a real effect being significant. A portion of the oxygen consumption represents reactions not involved in oxidative phosphorylation (Trimarchi et al. 2000). In any case, heat shock did not affect ATP content and so it can be concluded that heat shock did not cause major changes in energy availability at this stage. One possibility is that the loss of mitochondria by mitoptosis (Rivera et al. 2003) did not cause a reduction in ATP content either because ATP utilization was also reduced by heat shock or because heat shock increased the activity of enzymes involved in oxidative phosphorylation in unaffected mitochondria. Also, a decrease in mitochondrial ATP synthesis might have been compensated for by increased production of ATP by glycolysis, as suggested for some other cells types exposed to heat shock (Macouillard-Poulletier de Gannes et al. 2000).

The partial loss of mitochondria at the two-cell stage may not have a large effect on the energy-generating machinery of the cell because mitochondria are largely immature in the early stages of development (Van Blerkom et al. 1990, Plante \& King 1994), have a low ATP synthetic ability (Rozell et al. 1992, Khurana \& Niemann 2000), and do not replicate (Smith et al. 2000, Cummins 2001). Consequently, oxygen consumption is low during the early preimplantation stages (Leese 1991, Thompson et al. 1996). Perhaps embryos heat shocked at the two-cell stage become blocked in development at the eight-cell stage because increased cellular demands brought on by genome activation (Memili \& First 2000) cannot be met because of earlier damage to mitochondria or other organelles. However, there does not seem to be a major increase in oxygen consumption in the bovine embryo until compaction (Thompson et al. 1996).

An alternative explantation for the eight-cell block in embryos exposed to heat shock at the two-cell stage involves developmental changes in embryonic capacity for apoptosis. Heat shock-induced apoptosis first occurs between the eight-cell and the sixteen-cell stages in cattle (Paula-Lopes \& Hansen 2002). Perhaps, signals from mitochondria that were damaged at the two-cell stage were sufficient to induce apoptosis once the embryo reached the eight-cell stage. Blastomeres with a deficient number of mitochondria may overproduce ATP to meet the metabolic need of the blastomere, and this overproduction could itself trigger mitochondrial demise and send the cell through apoptosis (Skulachev 2002, Waterhouse 2003). The increase in cells with condensed nuclei could be evidence of apoptosis triggered as a result of mitochondrial damage (Burgoyne 1999). That only some nuclei were condensed could, in part, reflect asymmetrical distribution of mitochondria during cleavage. Such a phenomenon has been reported for human cleavage-stage embryos, resulting in some blastomeres having reduced mitochondrial inheritance and diminished ATP capacity (Van Blerkom et al. 2000).

The values for ATP content per embryo obtained in the present study $(0.26-0.30 \mathrm{pmol})$ are not directly comparable to the literature because there are no reports on ATP content in bovine embryos at the two-cell stage. The values are similar to those reported for matured oocytes in one study (0.18-0.38 pmol; Hashimoto et al. 2000) but lower than the values for matured oocytes of $0.85 \mathrm{pmol}$ found by Rieger (1997) and 1.6-2.5 pmol found by Stojkovic et al. (2001). In the cat, at least, ATP content is lower for two-cell embryos than for matured oocytes (Friestedt et al. 2001), and it is possible that a reduction in ATP content following fertilization and cleavage also 
occurs in cattle. The rate of oxygen consumption in embryos at $38.5^{\circ} \mathrm{C}$ was $\sim 2.8 \times 10^{-13} \mathrm{moles} / \mathrm{s}$. This value is closer to the value of $0.14 \times 10^{-13} \mathrm{moles} / \mathrm{s}$ for bovine morula reported by Shiku et al. (2001) than for values reported by Thompson et al. (1996) of $\sim 9 \times 10^{-11}$ moles/s for bovine embryos from day $0-4$ of culture. Reported values for bovine blastocysts range from 0.4$1.5 \times 10^{-9}$ moles/s (Thompson et al. 1996, Kaidi et al. 2001, Donnay et al. 2002). Reasons for the differences in absolute amounts are not known but could include methodology since the lower values in the present study and by Shiku et al. (2001) are based on electrochemical measurements of oxygen, while other papers cited above rely on quenching of pyrene fluorescence by oxygen. The electrochemical method employed here has been used extensively to characterize oxygen consumption in cultured islets of Langerhans (Jung et al. 1999a,b, 2000).

In summary, exposure of bovine embryos at the two-cell stage did not appear to cause a block to development by increasing oxygen free radicals or causing an immediate reduction in oxidative phosphorylation. Embryos did not become inhibited in development immediately after heat shock but rather progressed to the eight-cell stage before becoming blocked in development and developing condensed nuclei. It is likely that mitochondrial damage or other alterations in the embryo brought about by heat shock at the two-cell stage makes the embryo unable to proceed past the eight-cell stage, a critical time in embryo development when there is a surge in embryonic transcription (Barnes \& Eyestone 1990, Memili et al. 1998), and heat shock-induced apoptosis becomes possible (Paula-Lopes \& Hansen 2002).

\section{Acknowledgements}

The authors thank William Rembert for collecting ovaries and Jose Queijeiro for technical assistance. The authors extend special thanks to the following for their generosity: Marshall, Adam and Alex Chernin and employees of the Central Beef Packing Co. (Center Hill, FL, USA) for providing ovaries and Scott A Randell from Southeastern Semen Services (Wellborn, $\mathrm{FL}$, USA) for donating semen. This is Journal Series No. R-09876 of the Florida Agricultural Experiment Station. Grant support: USDA IFAFS 2001-52101-11318, USDA TSTAR 2001-34135-11150, NIH RO1-DK46960, and USDA NRICGP Grant no. 2002-35203-12664, and a grant from the University of Florida Research Opportunity Fund.

\section{References}

Alliston CW, Howarth B Jr \& Ulberg LC 1965 Embryonic mortality following culture in vitro of one- and two-cell rabbit eggs at elevated temperatures. Journal of Reproduction and Fertility 9 337-341.

Aréchiga CF \& Hansen PJ 1998 Response of preimplantation murine embryos to heat shock as modified by developmental stage and glutathione. In Vitro Cellular and Developmental Biology. Animal 34 655-659.
Aréchiga CF, Ealy AD \& Hansen PJ 1995 Evidence that glutathione is involved in thermotolerance of preimplantation murine embryos. Biology of Reproduction 52 1296-1301.

Baker MA, Cerniglia GJ \& Zaman A 1990 Microtiter plate assay for the measurement of glutathione and glutathione disulfide in large numbers of biological samples. Analytical Biochemistry 190 $360-365$.

Barnes FL \& Eyestone WH 1990 Early cleavage and the maternal to zygotic transition in bovine embryos. Theriogenology 33 $141-152$.

Burgoyne LA 1999 The mechanisms of pyknosis: hypercondensation and death. Experimental Cell Research 248 214-222.

Calderwood SK 1987 Role of energy in cellular responses to heat. In Temperature and Animal Cells, pp 213-233. Eds K Bowler \& BJ Fuller. Cambridge: Company of Biologists.

Cohen HJ \& Fridovich I 1971 Hepatic sulfite oxidase: purification and properties. Journal of Biological Chemistry 246 359-366.

Cole A \& Armour EP 1988 Ultrastructural study of mitochondrial damage in $\mathrm{CHO}$ cells exposed to hyperthermia. Radiation Research 115 421-435.

Cummins JM 2001 Mitochondria: potential roles in embryogenesis and nucleocytoplasmic transfer. Human Reproduction 7 $217-228$.

Donnay I, Feugang JM, Bernard S, Marchandise J, Pampfer S, Moens A \& Dessy F 2002 Impact of adding $5.5 \mathrm{mM}$ glucose to SOF medium on the development, metabolism and quality of in vitro produced bovine embryos from the morula to the blastocyst stage. Zygote 10 189-199.

Duchen MR 1999 Contributions of mitochondria to animal physiology: from homeostatic sensor to calcium signaling and cell death. Journal of Physiology 516 1-17.

Ealy AD, Drost M \& Hansen PJ 1993 Developmental changes in embryonic resistance to adverse effects of maternal heat stress in cows. Journal of Dairy Science 76 2899-2905.

Ealy AD, Howell JL, Monterroso VH, Aréchiga CF \& Hansen PJ 1995 Developmental changes in sensitivity of bovine embryos to heat shock and use of antioxidants and thermoprotectants. Journal of Animal Science 73 1401-1407.

Elliot DS \& Ulberg LC 1971 Early embryo development in the mammal. I. Effects of experimental alterations during first cell division in the mouse zygote. Journal of Animal Science 33 86-95.

Elliot DS, Burfering PJ \& Ulberg LC 1968 Subsequent development during incubation of fertilized mouse ova stressed by high ambient temperatures. Journal of Experimental Zoology 169 481-486.

Findly RC, Gillies RJ \& Shulman RG 1983 In vivo phosphorus-31 nuclear magnetic resonance reveals lowered ATP during heat shock of Tetrahymena. Science 219 1223-1225.

Flanagan SW, Moseley PL \& Buettner GR 1998 Increased flux of free radicals in cells subjected to hyperthermia: detection by electron paramagnetic resonance spin trapping. FEBS Letters 431 $285-286$.

Floridi A, Nista A, Paggi MG, Pellegrini L, Bagnato A, Fanciulli M \& Caputo A 1987 Effect of hyperthermia on electron transport in Erlich ascites tumor mitochondria. Experimental and Molecular Pathology 46 279-293.

Freistedt P, Stojkovic P, Wolf E \& Stojkovic M 2001 Energy status of nonmatured and in vitro-matured domestic cat oocytes and of different stages of in vitro-produced embryos: enzymatic removal of the zona pellucida increases adenosine triphosphate content and total cell number of blastocysts. Biology of Reproduction $\mathbf{6 5}$ $793-798$.

Fridovich I 1964 Competitive inhibition of xanthine oxidase by urea and guanidinium ion. Journal of Biological Chemistry 239 3519-3521.

Funk RHW, Nagel F, Wonka F, Krinke HE, Golfert F \& Hofer A 1999 Effects of heat shock on the functional morphology of cell organelles observed by video-enhanced microscopy. Anatomical Record 255 458-464. 
Goto Y, Noda Y, Mori T \& Nakano M 1993 Increased generation of reactive oxygen species in embryos cultured in vitro. Free Radical Biology and Medicine 15 69-75.

Gwazdauskas FC, McCaffrey C, McEvoy TG \& Sreenan JM 1992 In vitro preimplantation mouse embryo development with incubation temperatures of $37^{\circ} \mathrm{C}$ and $39^{\circ} \mathrm{C}$. Journal of Assisted Reproduction and Development 9 149-154.

Halestrap AP, McStay GP \& Clarke SJ 2002 The permeability transition pore complex: another view. Biochimie 84 153-166.

Hashimoto S, Minami N, Takakura R, Yamada M, Imai H \& Kashima $\mathbf{N} 2000$ Low oxygen tension during in vitro maturation is beneficial for supporting the subsequent development of bovine cumulus-oocyte complexes. Molecular Reproduction and Development $57353-360$.

Houghton FD, Thompson JG, Keneddy CJ \& Leese HJ 1996 Oxygen consumption and energy metabolism of the early mouse embryo. Molecular Reproduction and Development 44 476-485.

Ichas F \& Mazat JP 1998 From calcium signaling to cell death: two conformations for the mitochondrial permeability transition pore. Switching from low- to high-conductance state. Biochimica et Biophysica Acta 1366 33-50.

Jung SK, Gorski W, Aspinwall CA, Kauri LM \& Kennedy RT 1999a Oxygen microsensor and its application to single cells and mouse pancreatic islets. Analytical Chemistry 71 3642-3649.

Jung SK, Aspinwall CA \& Kennedy RT 1999b Detection of multiple patterns of oscillatory oxygen consumption in single mouse islets of Langerhans. Biochemical and Biophysical Research Communications 259 331-335.

Jung SK, Kauri LM, Qian WJ \& Kennedy RT 2000 Correlated oscillations in glucose consumption, oxygen consumption and intracellular free $\mathrm{Ca}^{2+}$ in single islets of Langerhans. Journal of Biological Chemistry 275 6642-6650.

Kaidi S, Bernard S, Lambert P, Massip A, Dessy F \& Donnay I 2001 Effect of conventional controlled-rate freezing and vitrification on morphology and metabolism of bovine blastocysts produced in vitro. Biology of Reproduction 65 1127-1134.

Khurana NK \& Niemann H 2000 Energy metabolism in preimplantation bovine embryos derived in vitro or in vivo. Biology of Reproduction $62847-856$.

Leese HJ 1991 Metabolism of the preimplantation mammalian embryo. Oxford Reviews of Reproductive Biology 13 35-72.

Lemasters JJ 1999 The mitochondrial permeability transition and the calcium, oxygen and $\mathrm{pH}$ paradoxes: one paradox after another Cardiovascular Research 44 470-473.

Macouillard-Poulletier de Gannes F, Merle M, Canioni P \& Voisin P] 1998 Metabolic and cellular characterization of immortalized human microglial cells under heat stress. Neurochemistry International 33 61-73.

Macouillard-Poulletier de Gannes F, Leducq N, Diolez P, Belloc F, Merle M, Canioni P \& Voisin PJ 2000 Mitochondrial impairment and recovery after heat shock treatment in a human microglial cell line. Neurochemistry International 36 233-241.

Memili E \& First NL 2000 Zygotic and embryonic gene expression in cow: a review of timing and mechanisms of early gene expression as compared with other species. Zygote 8 87-96.

Memili E, Dominko T \& First NL 1998 Onset of transcription in bovine oocytes and preimplantation embryos. Molecular Reproduction and Development 51 36-41.

Mueller-Klieser W 1984 Method for the determination of oxygen consumption rates and diffusion coefficients in multicellular spheroids. Biophysical Journal 46 343-348.

Ozawa M, Hirabayashi M \& Kanai Y 2002 Developmental competence and oxidative state of mouse zygotes heat-stressed maternally or in vitro. Reproduction $124683-689$.

Paula-Lopes FF \& Hansen PJ 2002 Heat shock-induced apoptosis in bovine preimplantation embryos is a developmentally-regulated phenomenon. Biology of Reproduction 66 1169-1177.

Paula-Lopes FF, Al-Katanani YM, Majewski AC, McDowell LR \& Hansen PJ 2003 Manipulation of antioxidant status fails to improve fertility of lactating cows or survival of heat-shocked embryos. Journal of Dairy Science 86 2343-2351.

Plante L \& King WA 1994 Light and electron microscopic analysis of bovine embryos derived by in vitro and in vivo fertilization. Journal of Assisted Reproduction and Development 11 515-529.

Putney DJ, Drost M \& Thatcher WW 1988 Embryonic development in superovulated dairy cattle exposed to elevated ambient temperature between days 1 to 7 post-insemination. Theriogenology 30 195-209.

Rieger D 1997 Batch analysis of the ATP content of bovine sperm, oocytes and early embryos using a scintillation counter to measure the chemiluminescence produced by the luciferin-luciferase reaction. Analytical Biochemistry 246 67-70.

Rivera RM \& Hansen PJ 2001 Development of cultured bovine embryos after exposure to high temperatures in the physiological range. Reproduction 121 107-115.

Rivera RM, Kelley KL, Erdos GW \& Hansen PJ 2003 Alterations in ultrastructural morphology of two-cell bovine embryos produced in vitro and in vivo following a physiologically-relevant heat shock. Biology of Reproduction 69 2068-2077.

Rivera RM, Kelley KL, Erdos GW \& Hansen PJ 2004 Reorganization of microfilaments and microtubules by thermal stress in two-cell bovine embryos. Biology of Reproduction 70 1852-1862.

Rozell MD, Williams JE \& Butler JE 1992 Changes in concentration of adenosine triphosphate and adenosine diphosphate in individual preimplantation sheep embryos. Biology of Reproduction 47 866-870.

Sakatani M, Kobayashi S-I \& Takahashi M 2004 Effects of heat shock on in vitro development and intracellular oxidative state of bovine preimplantation embryos. Molecular Reproduction and Development 67 77-82.

Shiku H, Shiraishi T, Ohya H, Matsue T, Abe H, Hoshi H \& Kobayashi M 2001 Oxygen consumption of single bovine embryos probed by scanning electrochemical microscopy. Analytical Chemistry $\mathbf{7 3}$ $3751-3758$

Skibba JL, Stadnicka A, Kalbfleisch JH \& Powers RH 1989 Effects of hyperthermia on xanthine oxidase activity and glutathione levels in the perfused rat liver. Journal of Biochemical Toxicology 4 119-125.

Skulachev VP 2002 Programmed death phenomena: from organelle to organism. Annals of the New York Academy of Sciences 959 214-237.

Smith LC, Bordignon V, Garcia JM \& Meirelles FV 2000 Mitochondrial genotype segregation and effects during mammalian development: applications to biotechnology. Theriogenology $\mathbf{5 3}$ $35-46$.

Soto P, Natzke RP \& Hansen PJ 2003 Identification of possible mediators of embryonic mortality caused by mastitis: actions of lipopolysaccharide, prostaglandin $F_{2 \alpha}$ the nitric oxide generator, sodium nitroprusside dihydrate, on oocyte maturation and embryonic development in cattle. American Journal of Reproductive Immunology 50 263-272.

Stojkovic M, Machado SA, Stojkovic P, Zakhartchenko V, Hutzler P, Gonçalves PB \& Wolf E 2001 Mitochondrial distribution and adenosine triphosphate content of bovine oocytes before and after in vitro maturation: correlation with morphological criteria and developmental capacity after in vitro fertilization and culture. Biology of Reproduction 64 904-909.

Thompson JG 2000 In vitro culture and embryo metabolism of cattle and sheep embryos - a decade of achievement. Animal Reproduction Science 60-61 263-275.

Thompson JG, Partridge RJ, Houghton FD, Cox CI \& Leese HJ 1996 Oxygen uptake and carbohydrate metabolism by in vitro derived bovine embryos. Journal of Reproduction and Fertility $\mathbf{1 0 6}$ 299-306.

Trimarchi JR, Liu L, Porterfield M, Smith PJS \& Keefe DL 2000 Oxidative phosphorylation-dependent and -independent oxygen consumption by individual preimplantation mouse embryos. Biology of Reproduction 62 1866-1874. 
Van Blerkom J, Bell J \& Weipz D 1990 Cellular and developmental biological aspects of bovine meiotic maturation, fertilization and preimplantation embryogenesis in vitro. Journal of Electron Microscopy Technique 16 298-323.

Van Blerkom J, Davis P \& Alexander S 2000 Differential mitochondrial distribution in human pronuclear embryos leads to disproportionate inheritance between blastomeres: relationship to microtubular organization, ATP content and competence. Human Reproduction 15 2621-2633.

Waterhouse NJ 2003 The cellular energy crisis: mitochondria and cell death. Medicine and Science in Sports and Exercise 35 $105-110$.

Welch WJ \& Suhan JP 1985 Morphological study of the mammalian stress response: characterization of changes in cytoplasmic organelles, cytoskeleton and nucleoli and appearance of intranuclear actin filaments in rat fibroblasts after heat-shock treatment. Journal of Cell Biology 101 1198-1211.

Wettemen RP \& Baze FW 1985 Influence of environmental temperature on prolificacy of pigs. Journal of Reproduction and Fertility Supplement 33 199-208.

Received 17 December 2003

First decision 23 February 2004

Revised manuscript received 5 April 2004

Accepted 28 April 2004 